\title{
SELEKSI KARAKTER PERTUMBUHAN POPULASI IKAN MAS (Cyprinus carpio) RELATIF TAHAN KOI HERPES VIRUS
}

\author{
Didik Ariyanto, Erma Primanita Hayuningtyas, dan Khairul Syahputra \\ Balai Penelitian Pemuliaan Ikan \\ Jl. Raya 2 Sukamandi, Subang, Jawa Barat 41256 \\ E-mail: didik_ski@yahoo.com
}

(Naskah diterima: 16 Februari 2012; Disetujui publikasi: 4 Januari 2013)

\begin{abstract}
ABSTRAK
Strain Rajadanu merupakan populasi ikan mas yang mempunyai daya tahan terhadap serangan koi herpes virus (KHV) relatif lebih baik dibandingkan strain lainnya. Namun demikian, populasi ikan dengan daya tahan yang tinggi diduga mempunyai laju pertumbuhan yang lebih lambat. Hal ini karena adanya fenomena sharing energy untuk berbagai karakter yang berbeda. Dalam kegiatan seleksi, salah satu strategi yang dapat ditempuh untuk mengantisipasi fenomena tersebut adalah dengan melakukan seleksi secara bersamaan (tandem selection) terhadap karakter-karakter tersebut. Penelitian ini bertujuan untuk mendapatkan populasi ikan mas strain Rajadanu dengan laju pertumbuhan cepat, sebagai bagian dari program perakitan strain unggul ikan mas tahan KHV. Sebagai hewan uji adalah populasi dasar (FO) sintetik yang dibentuk tahun 2010, terdiri atas 2 cohort ikan mas strain Rajadanu dengan masing-masing populasi terdiri atas 10 famili yang bersifat full-sib. Seleksi dilakukan menggunakan metode seleksi individu (mass selection) pada saat bobot rata-rata populasi mencapai ukuran konsumsi, yaitu antara 200-300 g/ekor. Cut off seleksi ditentukan berdasarkan hasil sampling sebelum kegiatan seleksi dilakukan, yaitu bobot individu terendah pada $20 \%$ individu terbaik, sebesar $400 \mathrm{~g}$. Hasil penelitian menunjukkan bahwa bobot rata-rata pada cohort 1 dan 2 masing-masing sebesar 271,91 g dan 247,49 g dengan bobot rata-rata populasi terseleksi masing-masing cohort sebesar $558,18 \mathrm{~g}$ dan 528,08 g, sehingga menghasilkan nilai diferensial seleksi sebesar 286,27 g dan 280,39 g. Hasil analisis terhadap nilai heritabilitas (dalam arti luas/broad sense) karakter bobot kedua cohort ikan mas tersebut sebesar $42 \%$ dan $30 \%$. Berdasarkan hasil tersebut, prediksi respon seleksi yang akan diperoleh pada generasi selanjutnya (F1) pada masing-masing cohort sebesar $123,01 \mathrm{~g}$ dan $84,12 \mathrm{~g}$ setara dengan $45,27 \%$ dan $33,96 \%$.
\end{abstract}

KATA KUNCI: ikan mas, tahan KHV, tumbuh cepat, seleksi

ABSTRACT: Selection on growth character of the resistant to koi herpes virus population of common carp. By: Didik Ariyanto, Erma Primanita Hayuningtyas, and Khairul Syahputra

Rajadanu was relatively more resistance strain of common carp to koi herpes virus (KHV) infection than others. But, it is well known that the resistance and viability of animals included fish is inversely related to growth rate, one of the most important character in aquaculture. To avoid this undesirable corellation, tandem selection could be applicated to get the fast growth and resistant fish in the same population. This fast growth of common carp selection in this report was a part of breeding program on establishment the specific pathogen resistance line of common carp to KHV. In 2010, there were 2 cohorts of synthetic base population of Rajadanu strain of common carp, which each cohort was consist of 10 full-sib families. This study was 
conducted to get the individual selected population on growth character of the broodstock candidate from each cohort. Selection was conducted at the consumption size of fish, ranged from 200-300 g. Based on the lowest individual weight of $20 \%$ top population, cut-off for minimum selected fish was determined at $400 \mathrm{~g}$. The results showed that the average of body weight of cohort 1 and 2 were $271.91 \mathrm{~g}$ and $247.49 \mathrm{~g}$ and the average body weight of selected population for cohort 1 and 2 were $558.18 \mathrm{~g}$ and $528.08 \mathrm{~g}$, respectively. Analysis on the diferential selection and the broad sense of heritability resulted $286.27 \mathrm{~g}, 280.39 \mathrm{~g}$ and $42 \%, 30 \%$ for cohort 1 and 2, respectively. Based on this results, prediction of response to selection for cohort 1 and 2 in the next generation (F1) were $123.01 \mathrm{~g}$ and $84.12 \mathrm{~g}$, equivalent with $45.27 \%$ and $33.96 \%$, respectively.

\section{KEYWORDS: common carp, resistant to KHV, fast growth, selection}

\section{PENDAHULUAN}

Ikan mas (Cyprinus carpio) merupakan komoditas yang cukup banyak diproduksi oleh pembudidaya di Indonesia dan telah memberikan kontribusi ekonomi cukup besar. Hal ini tercermin dari angka produksi ikan mas yang menduduki urutan pertama dari produksi ikan hasil budidaya air tawar pada skala nasional selama kurun waktu 1992-1997 (Anonim, 1999). Timbulnya wabah penyakit yang disebabkan oleh virus KHV (Koi Herpes Virus) yang menyerang ikan mas sejak tahun 2002 membuat usaha budidaya ikan tersebut mengalami penurunan yang sangat drastis (Sunarto, 2005; Sunarto et al., 2005). Kerugian yang ditimbulkan penyakit KHV pada tahun 2002 mencapai lebih dari US\$ 10.000.000 (Rukmono, 2005). Selanjutnya wabah KHV menyebar di beberapa sentra budidaya ikan mas seperti di Jawa Barat, Sumatera Barat, Sumatera Utara hingga ke Sulawesi dan Irian.

Dalam rangka penanggulangan dan pengendalian penyakit KHV, beberapa strategi alternatif telah dilakukan antara lain manajemen kesehatan ikan secara terpadu, penggunaan ikan mas bebas KHV, aplikasi imunopropilaksis dan lain-lain (Taukhid et al., 2005). Namun demikian, alternatif penanggulangan penyakit melalui perbaikan genetik ikan mas belum dilakukan sehingga perlu diinisiasi. Fjalestad et al. (1993) menjelaskan bahwa kegiatan seleksi ikan untuk mendapatkan populasi tahan terhadap penyakit relatif efektif dilakukan.

Hasil evaluasi terhadap 5 populasi strain ikan mas hasil koleksi Balai Penelitian Pemuliaan Ikan (BPPI), Sukamandi tahun 2010, yaitu Rajadanu, Wildan, Sutisna, Majalaya, dan Sinyonya, menunjukkan bahwa terdapat variasi pada karakter daya tahan terhadap KHV antar populasi (Ariyanto et al., 2010a). Lebih lanjut laporan tersebut menjelaskan bahwa strain Rajadanu mempunyai daya tahan terhadap KHV relatif lebih baik dibanding strain lainnya. Berdasarkan hasil evaluasi tersebut, strain Rajadanu yang berasal dari Kabupaten Kuningan berpotensi baik untuk dikembangkan sebagai varietas unggul tahan KHV.

Pembentukan populasi dasar ikan mas tahan KHV menggunakan strain Rajadanu pada tahun 2010 telah mendapatkan populasi yang terdiri atas 2 cohort dengan masingmasing cohort terdapat 10 famili yang bersifat full-sib (Ariyanto et al., 2010b). Penelitian ini bertujuan untuk mengevaluasi pertumbuhan, mengestimasi nilai heritabilitas, mendapatkan populasi terseleksi serta mengestimasi nilai respon seleksi yang dilakukan pada populasi dasar ikan mas terhadap generasi selanjutnya, terutama pada karakter pertumbuhan yang diindikasikan dengan bobot badan.

\section{BAHAN DAN METODE}

Bahan penelitian ini adalah populasi dasar sintetik ikan mas strain Rajadanu yang terdiri atas 2 cohort dengan masing-masing cohort terdapat 10 famili yang bersifat full-sib. Pemijahan induk secara buatan dilakukan pada tahun 2010 . Ukuran bobot benih dalam setiap populasi bervariasi antara 20-30 g/ekor.

\section{Pemeliharaan Benih Hingga Calon Induk}

Dua populasi calon induk ikan mas dipelihara di 2 unit kolam tanah ukuran $400 \mathrm{~m}^{2}$ dengan teknologi pemeliharaan yang setara. Kepadatan yang diaplikasikan adalah 10 ekor/ $\mathrm{m}^{2}$. Pakan buatan dengan kandungan protein kasar 28\%, diberikan sebanyak 2,5-10,0\% dari biomassa ikan per hari, menurun setiap satu 
bulan. Pemberian pakan diberikan dua kali sehari, yaitu pada pagi hari (08.00) dan sore hari (16.00). Sampling bobot dalam rangka penyesuaian kebutuhan pakan ikan dilakukan setiap satu bulan.

\section{Seleksi Karakter Pertumbuhan}

Seleksi dilakukan pada saat bobot rata-rata populasi ikan mas mencapai ukuran konsumsi, yaitu antara 200-300 g/ekor. Kegiatan seleksi dilakukan dengan menimbang bobot masingmasing individu calon induk pada kedua populasi. Bobot terendah populasi terseleksi ditentukan berdasarkan hasil sampling sebelum seleksi dilakukan. Bobot terendah pada $20 \%$ terbaik populasi sampel dijadikan ketetapan sebagai bobot terendah populasi terseleksi (selection cut-off). Individu-individu terseleksi berdasarkan ketetapan cut-off seleksi dipelihara sebagai calon induk dan digunakan sebagai bahan pada kegiatan tahap selanjutnya. Selain memilih populasi terseleksi, juga dilakukan pemilihan $20 \%$ populasi dengan bobot rata-rata sebagai populasi kontrol internal.

\section{Analisis Data}

Analisis data dilakukan secara deskriptif terhadap laju pertumbuhan, nilai diferensial seleksi, estimasi nilai heritabilitas $\left(h^{2}\right)$, dan respons seleksi.

1. Laju pertumbuhan spesifik (SGR), dihitung berdasarkan formula sebagai berikut:

$$
\mathrm{SGR}=\frac{\ln W \mathrm{t}-\ln \mathrm{Wo}_{\mathrm{O}}}{\mathrm{t}} \times 100 \%
$$

di mana:

$$
\begin{aligned}
& \mathrm{SGR}=\text { Laju pertumbuhan spesifik (\%) } \\
& \mathrm{Wt}=\text { Bobot awal } \\
& \mathrm{Wo}=\text { Bobot pada waktu } \mathrm{t} \\
& \mathrm{t}=\text { Waktu pemeliharaan }
\end{aligned}
$$

2. Nilai diferensial seleksi (S), dihitung berdasarkan bobot rata-rata populasi awal dan bobot rata-rata populasi terseleksi. Nilai diferensial seleksi dihitung berdasarkan formula sebagai berikut:

$$
S=\chi^{\prime}-\chi
$$

di mana:

$S=$ Diferensial seleksi

$\chi^{\prime}=$ Rata-rata bobot populasi terseleksi

$\chi=$ Rata-rata bobot populasi awal

\section{Estimasi nilai heritabilitas dalam arti luas $\left(h^{2}\right)$}

Estimasi heritabilitas dalam arti luas dilakukan menggunakan metode analysis of variance (ANOVA) berdasarkan bobot individu ikan dalam setiap famili. Varian genotip merupakan nilai keragaman fenotipik individu dalam populasi (famili) yang disebabkan oleh faktor genetik, sedangkan varian fenotip merupakan keragaman fenotipik individu dalam populasi (famili) yang disebabkan oleh adanya interaksi antara faktor genetik, faktor lingkungan serta interaksi antara keduanya. Anova dan nilai harapan percobaan pada penelitian ini disajikan pada Tabel 1.

Untuk mengestimasi nilai heritabilitas dalam arti luas, diperlukan estimasi nilai varian genotip $\left(\sigma_{g}^{2}\right)$ dan varian fenotip $\left(\sigma_{p}^{2}\right)$ sebagai berikut:

$$
\begin{gathered}
\sigma_{g}^{2}=\frac{M 2-M 1}{r} \\
\sigma_{p}^{2}=\frac{M 2-M 1}{r}+\frac{M 1}{r} \\
h^{2}(B S)=\frac{\sigma_{g}^{2}}{\sigma_{g}^{2}+\left(\sigma_{e}^{2} / r\right)} \times 100 \%
\end{gathered}
$$

di mana:

$\sigma_{g}^{2}=$ Varian genotip

$\sigma_{p}^{2}=$ Varian fenotip

$\sigma_{\mathrm{e}}^{2}=$ Varian lingkungan

$\mathrm{M} 1$ = Kuadrat tengah genotip/famili

$\mathrm{M} 2$ = Kuadrat tengah galat $\mathrm{T}$ varian lingkungan $\mathrm{R}=$ Ulangan

4. Estimasi respons seleksi (R), merupakan nilai prediksi perbaikan genetik yang diharapkan terjadi pada generasi berikutnya sebagai akibat kegiatan seleksi yang dilakukan pada generasi sebelumnya. Nilai respon seleksi diestimasi menggunakan formula sebagai berikut:

$$
\mathrm{R}=\mathrm{S} \chi \mathrm{h}^{2}
$$

di mana:

$\mathrm{R}=$ Respons seleksi
$\mathrm{S}=$ Diferensial seleksi
$\mathrm{h}^{2}=$ Heritabilitas

Dalam penelitian ini juga diamati beberapa nilai kualitas air meliputi suhu, kandungan oksigen terlarut, $\mathrm{pH}$ dan amoniak yang dianalisis setiap dua minggu sekali. 
Tabel 1. Anova dan nilai harapan percobaan berdasarkan bobot individu pada 10 famili ikan mas

Table 1. Anova and the expected values based on individual body weight of 10 families of common carp

\begin{tabular}{lccc}
\hline $\begin{array}{c}\text { Sumber keragaman } \\
\text { Source of } \\
\text { variance }\end{array}$ & $\begin{array}{c}\text { Derajat bebas } \\
\text { Degree of } \\
\text { freedom }\end{array}$ & $\begin{array}{c}\text { Kuadrat tengah } \\
\text { Means of } \\
\text { square }\end{array}$ & $\begin{array}{c}\text { Nilai harapan } \\
\text { Expected values }\end{array}$ \\
\hline $\begin{array}{l}\text { Ulangan (Repeater) } \\
\text { Genotip (famili) }\end{array}$ & $(\mathrm{r}-1)$ & $\mathrm{M} 2$ & $\sigma_{\mathrm{e}}^{2}+\mathrm{r}\left(\sigma_{\mathrm{g}}^{2}+\sigma_{\mathrm{gl}}^{2}+\sigma_{\mathrm{gy}}^{2}+\sigma_{\mathrm{gly}}^{2}\right)$ \\
$\begin{array}{l}\text { Genotype (family) } \\
\text { Galat }\end{array}$ & $(\mathrm{g}-1)$ & $\mathrm{M} 1$ & $\sigma_{\mathrm{e}}^{2}$ \\
\hline
\end{tabular}

Keterangan (Note):

$\sigma_{g}^{2}=$ Varian genotip

$\sigma_{g l}^{{ }^{g}}=$ Interaksi antara varian genotip dengan varian lingkungan terkait lokasi

$\sigma_{g y}^{2}=$ Interaksi antara varian genotip dengan varian lingkungan terkait waktu (musim)

$\sigma_{g l y}^{2}=$ Interaksi antara varian genotip dengan varian lingkungan tekait lokasi dan waktu (musim)

\section{HASIL DAN BAHASAN}

Hasil pengamatan bobot rata-rata setiap bulan yang menunjukkan pola pertumbuhan masing-masing cohort populasi dasar calon induk ikan mas selama empat bulan disajikan pada Gambar 1 .

Secara umum, pertumbuhan bobot calon induk ikan mas pada penelitian ini relatif mengikuti pola yang normal untuk perkembangan bobot ikan. Hingga bulan kedua, peningkatan bobot rata-rata relatif rendah, namun demikian, pada bulan-bulan berikutnya perkembangan bobot rata-rata mengalami peningkatan yang relatif pesat. Pada tahap ini, pertumbuhan sudah berada pada tahap percepatan. Pada akhir bulan ke-empat, bobot rata-rata individu dalam kedua populasi sudah mencapai ukuran konsumsi, yaitu antara 200$300 \mathrm{~g}$.

Dalam kegiatan seleksi, semua individu calon induk ikan mas dipanen dan ditimbang. Berdasarkan data yang diperoleh, dilakukan analisis pola distribusi bobot individu calon induk ikan mas pada kedua cohort populasi dasar sintetik tersebut. Pola sebaran atau

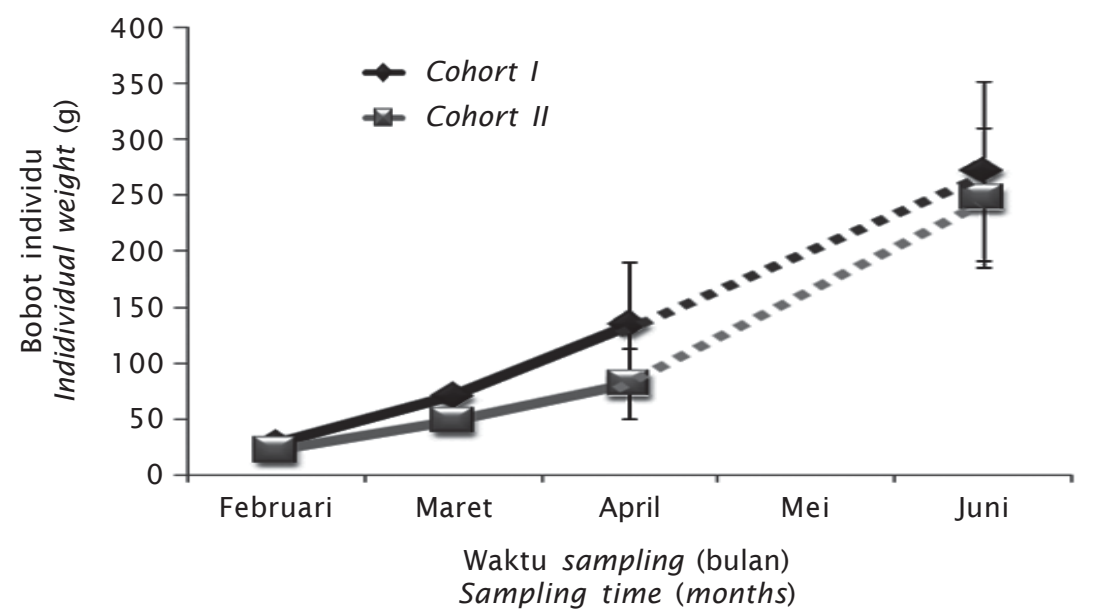

Gambar 1. Pola pertumbuhan populasi calon induk ikan mas selama 4 bulan

Figure 1. The pattern of growth of common carp broodstock candidate for 4 month period 
distribusi bobot individu calon induk ikan mas strain Rajadanu dan nilai cut off seleksi disajikan pada Gambar 2.

Distribusi bobot individu calon induk ikan mas dalam penelitian ini cenderung mempunyai skewness positif atau kemiringan ke arah kanan. Hal ini mengindikasikan bahwa secara umum jumlah individu yang mempunyai bobot kurang dari bobot rata-rata populasi relatif lebih banyak. Berdasarkan data bobot individu, selanjutnya dilakukan estimasi nilai heritabilitas dalam arti luas (broad sense of heritability), yaitu dengan menghitung nilai varian genotip dan varian fenotip pada masingmasing populasi (cohort).

Berdasarkan hasil sampling, bobot individu terendah pada $20 \%$ individu terbaik berada pada bobot $400 \mathrm{~g}$. Nilai tersebut selanjutnya ditetapkan sebagai titik selection cut off populasi calon induk ikan mas pada penelitian. Berdasarkan ketetapan tersebut, jumlah individu yang terseleksi pada populasi cohort 1 sebanyak 96 ekor atau setara dengan 17,98\% dan pada populasi cohort 2 diperoleh 164 ekor atau setara dengan $22,53 \%$. Hasil seleksi individu tersebut selanjutnya digunakan untuk menganalisis beberapa parameter genetik antara lain nilai rata-rata populasi awal, nilai rata-rata populasi terseleksi, nilai diferensial seleksi serta estimasi respon seleksi pada generasi selanjutnya. Hasil analisis beberapa parameter genetik pada populasi ikan mas dalam penelitian ini disajikan pada Tabel 2 .

Berdasarkan Tabel 2 terlihat bahwa laju pertumbuhan ikan mas pada penelitian ini berada dalam kategori normal. Estimasi peningkatan mutu genetik sebagai respon terhadap seleksi yang dilakukan pada karakter
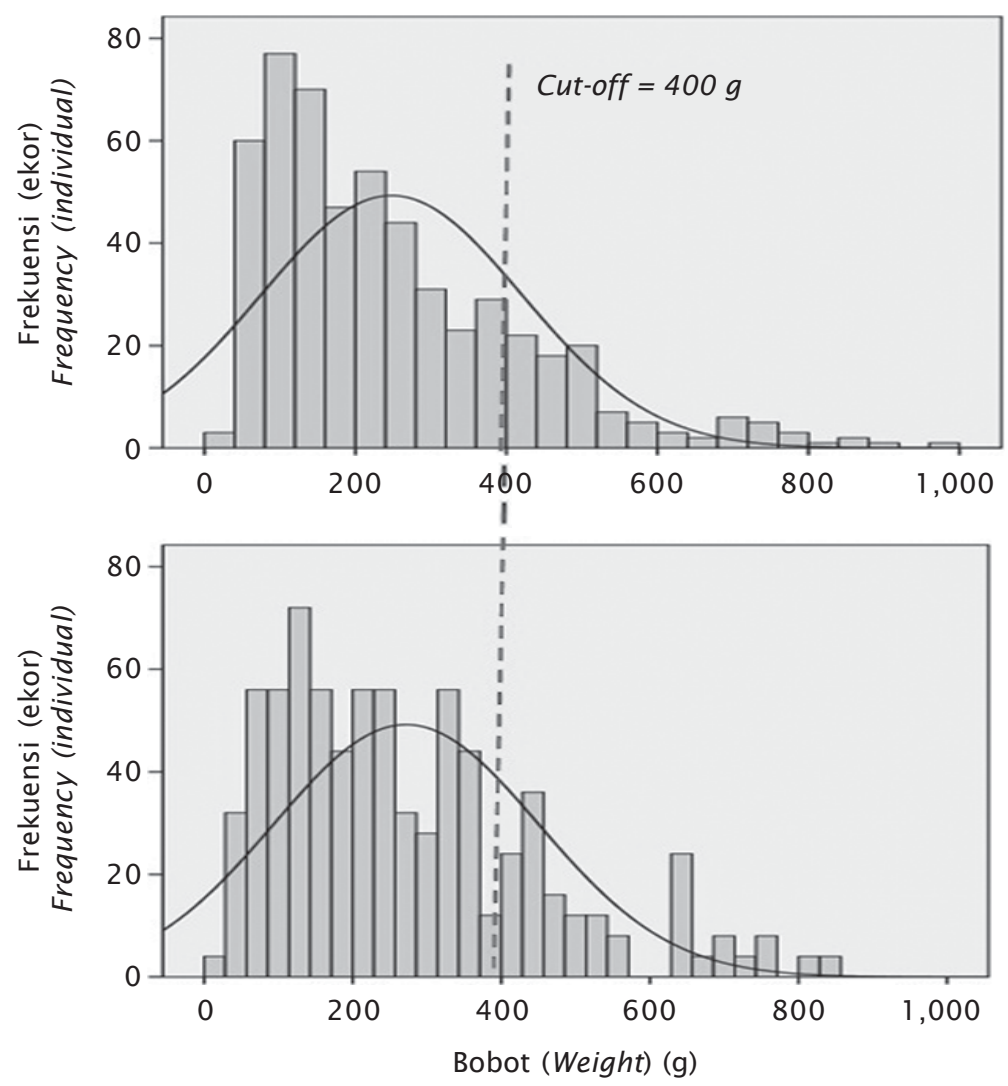

Gambar 2. Pola sebaran atau distribusi bobot individu populasi calon induk ikan mas strain Rajadanu

Figure 2. The pattern of individual weight distribution of broodstock candidate of Rajadanu common carp strain 
Tabel 2. Laju pertumbuhan dan beberapa parameter genetika populasi calon induk ikan mas strain Rajadanu hasil seleksi

Table 2. Growth rate and population genetic parameters of selected broodstock candidate of Rajadanu common carp strain

\begin{tabular}{|c|c|c|}
\hline $\begin{array}{l}\text { Parameter } \\
\text { Parameters }\end{array}$ & $\begin{array}{c}\text { Kelompok } \\
\text { Cohort } 1\end{array}$ & $\begin{array}{c}\text { Kelompok } \\
\text { Cohort } 2\end{array}$ \\
\hline $\begin{array}{l}\text { Laju pertumbuhan spe sifik (\%) } \\
\text { Specific growth rate (\%) }\end{array}$ & 2.18 & 2.01 \\
\hline $\begin{array}{l}\text { Bobot rata-rata populasi }(\mathrm{g}) \\
\text { Individual weight of population }(\mathrm{g})\end{array}$ & 271.91 & 247.69 \\
\hline $\begin{array}{l}\text { Bobot rata-rata individu tersele ksi (g) } \\
\text { Selected individual weight (g) }\end{array}$ & 558.18 & 528.08 \\
\hline $\begin{array}{l}\text { Dife rensial seleksi }(\mathrm{g}) \\
\text { Selection differential }(\mathrm{g})\end{array}$ & 286.27 & 280.39 \\
\hline $\begin{array}{l}\text { Varian genotip } \\
\text { Genotype variance }\end{array}$ & 140.59 & 18.00 \\
\hline $\begin{array}{l}\text { Varian fenotip } \\
\text { Phenotype variance }\end{array}$ & 336.50 & 59.55 \\
\hline $\begin{array}{l}\text { Estimasi he ritabilitas (arti luas) (\%) } \\
\text { Heritability estimation (broad sense) (\%) }\end{array}$ & 42.00 & 30.00 \\
\hline $\begin{array}{l}\text { Respons seleksi }(\mathrm{g}) \\
\text { Response to selection }(\mathrm{g})\end{array}$ & 123.01 & 84.12 \\
\hline
\end{tabular}

pertumbuhan yang diindikasikan dengan bobot individu relatif tinggi. Hasil ini memberikan harapan adanya peningkatan laju pertumbuhan pada populasi F1 sebesar 33,96$45,27 \%$ dibandingkan dengan populasi FO.

Hasil analisis kualitas media pemeliharaan calon induk ikan mas selama percobaan disajikan pada Tabel 3.
Kualitas air media pemeliharaan calon induk ikan mas selama penelitian masih sesuai dengan kebutuhan ikan air tawar. Fluktuasi kandungan oksigen terlarut harian tercatat berkisar antara 1,30-6,24 mg/L. Kondisi oksigen rendah biasanya terjadi pada pagi hari. Namun demikian, calon induk ikan mas pada penelitian ini masih mampu mentoleransi

Tabel 3. Nilai kualitas air media pemeliharaan calon induk ikan mas di kolam percobaan

Table 3. Water quality value of rearing of common carp broodstock candidate

\begin{tabular}{lcc}
\hline \multicolumn{1}{c}{$\begin{array}{c}\text { Parameter } \\
\text { Parameters }\end{array}$} & $\begin{array}{c}\text { Nilai } \\
\text { Value }\end{array}$ & $\begin{array}{c}\text { Referensi(Boyd, 1990) } \\
\text { References }\end{array}$ \\
\hline Suhu (Temperature) $\left({ }^{\circ} \mathrm{C}\right)$ & $26.5-33.6$ & $25.0-32.0$ \\
Oksigen terlarut & $1.30-6.24$ & $>5$ \\
Dissolved oxygen (mg/L) & $6.22-7.67$ & $6.5-9.0$ \\
$\mathrm{pH}$ & $0-0.33$ & $<0.5$ \\
Amoniak (Ammonia) $(\mathrm{mg} / \mathrm{L})$ & $0-0.1$ & $<1.0$ \\
Nitrit (Nitrite) $(\mathrm{mg} / \mathrm{L})$ & & \\
\hline
\end{tabular}


kondisi tersebut. Secara umum, kualitas air pemeliharaan yang relatif optimal tersebut mendukung dalam mempertahankan tingkat sintasan benih serta berperan penting dalam optimasi pertumbuhan dari setiap individu calon induk ikan mas.

\section{Pertumbuhan dan Distribusi Bobot Individu}

Flajshans \& Hulata (2011) menjelaskan bahwa pada kondisi normal, laju pertumbuhan spesifik harian ikan mas mencapai $2-4 \%$. Berdasarkan hal tersebut, pertumbuhan populasi ikan mas strain Rajadanu dalam penelitian ini termasuk dalam kategori normal. Namun demikian, pada akhir masa pemeliharaan selama empat bulan masih ditemukan individuindividu dengan bobot kurang dari $100 \mathrm{~g}$, meskipun terdapat juga individu-individu dengan bobot lebih dari $500 \mathrm{~g}$. Kisaran bobot individu yang sangat lebar ini menunjukkan tingginya variasi fenotip pada populasi ikan mas. Tingginya variasi fenotip ini memberikan harapan besar terhadap keberhasilan seleksi yang dilakukan. Hal ini karena variasi fenotip berkorelasi positif dengan variasi genotip. Jika variasi fenotipnya tinggi diharapkan populasi tersebut juga mempunyai variasi genotip yang tinggi (Tave, 1993; Noor, 2000). Tingginya variasi genotip pada populasi ikan mas ini memberikan peluang untuk dilakukannya pemilihan genotip-genotip yang diharapkan. Seleksi tidak menciptakan genotip baru, tetapi eksploitasi varian genotip khususnya varian aditif $\left(V_{A}\right)$ akan merubah frekuensi gen sesuai dengan arah seleksi yang dilakukan. Dengan demikian seleksi akan meningkatkan mutu genetik secara kuantitatif dengan sasaran akhir untuk mendapatkan induk unggul sebagai tetua (Tave, 1993; Hardjosubroto, 1994; Warwick et al., 1995; Falconer, 1981).

Kurva distribusi bobot individu pada kedua populasi ikan mas (Gambar 2) menunjukkan skewness positif atau kemiringan ke arah kanan. Kondisi ini mengindikasikan bahwa sebagian besar individu pada kedua populasi tersebut mempunyai bobot kurang dari bobot rata-rata populasi. Implikasi dari hal tersebut adalah jumlah individu yang mempunyai ukuran besar relatif sedikit. Namun demikian, seleksi karakter bobot individu kedua populasi ikan mas berdasarkan cut-off seleksi pada penelitian ini mendapatkan populasi terseleksi sebanyak 17,95\% pada cohort 1 dan 22,53\% pada cohort 2. Berdasarkan hasil tersebut, rata- rata populasi terseleksi untuk kedua populasi sebesar $20,24 \%$. Hasil ini sesuai dengan target seleksi sebesar $20 \%$ atau setara dengan nilai intensitas seleksi sebesar 1,4 (Tave, 1993). Semakin tinggi nilai intensitas seleksi akan menghasilkan nilai respon seleksi yang semakin baik sehingga peningkatan genetik pada generasi berikutnya juga akan semakin besar. Namun demikian, untuk mendapatkan nilai intensitas seleksi yang tinggi harus dilakukan dengan menurunkan nilai persentase seleksi. Jika nilai persentase seleksi terlalu rendah, dikhawatirkan jumlah individu yang terseleksi terlalu sedikit sehingga tidak memenuhi jumlah Ne (effective breeding number) pada pembentukan generasi berikutnya. Kondisi ini dikhawatirkan akan berdampak pada tingginya tingkat inbreeding yang terjadi antar generasi. Hal ini didukung oleh Kirpichnikov et al. (1993) yang melaporkan bahwa pada kegiatan seleksi ikan mas strain lokal (Krasnodar common carp), intensitas seleksi yang rendah menghasilkan jumlah individu terseleksi semakin sedikit. Hal ini berdampak terhadap peningkatan laju inbreeding pada generasi-generasi yang diperoleh berikutnya. Berdasarkan pertimbangan tersebut, persentase seleksi sebesar 20,24\% pada penelitian ini merupakan nilai yang cukup optimal.

\section{Heritabilitas dan Respons Seleksi}

Heritabilitas suatu karakter menjelaskan seberapa besar keragaman (variance) genotip berpengaruh terhadap keragaman fenotip (Noor, 2000). Dalam pengertian tersebut, heritabilitas terbagi menjadi dua macam, yaitu heritabilitas dalam arti luas (broad sense of heritability) dan heritabilitas dalam arti sempit (narrow sense of heritability). Heritabilitas dalam arti luas merupakan rasio antara keragaman genotip secara umum terhadap keragaman fenotip. Dalam hal ini, keragaman genotip melibatkan unsur-unsur keragaman aditif dan non aditif (keragaman dominan dan epistasi), sedangkan perhitungan heritabilitas dalam arti sempit tidak melibatkan unsur-unsur keragaman non aditif. Dalam penelitian ini, digunakan estimasi nilai heritabilitas dalam arti luas karena dua pertimbangan, yaitu: 1) Secara teknis, perhitungan heritabilitas dalam arti luas lebih mudah dilakukan. Hal ini karena keterbatasan materi yang tersedia, yaitu satu generasi yang terdiri atas beberapa genotip, dalam hal ini adalah famili-famili yang ter- 
bentuk; 2) Secara fungsional, hasil perhitungan heritabilitas dalam arti luas dapat digunakan sebagai dasar estimasi awal perhitungan respon seleksi yang akan berdampak terhadap peningkatan mutu genetik pada generasi selanjutnya. Pada penelitian ini, nilai heritabilitas dalam arti luas yang diperoleh pada populasi ikan mas cohort 1 dan 2 masingmasing sebesar $42 \%$ dan $30 \%$. Berdasarkan hasil tersebut, prediksi respon seleksi yang akan diperoleh pada generasi selanjutnya (F1) pada masing-masing cohort sebesar $123,01 \mathrm{~g}$ dan $84,12 \mathrm{~g}$ setara dengan peningkatan mutu genetik sebesar $45,27 \%$ dan $33,96 \%$.

Nilai heritabilitas karakter bobot badan ikan mas dalam penelitian ini termasuk dalam kategori sedang hingga tinggi (Tave, 1993; Noor, 2000). Jika dibandingkan dengan beberapa hasil penelitian sebelumnya, nilai heritabilitas, respon seleksi dan kemajuan genetik populasi ikan mas pada penelitian ini relatif baik. Hulata (1995); Vandeputte (2003) dan Nielsen et al. (2010) menjelaskan bahwa nilai heritabilitas karakter pertumbuhan ikan mas pada umumnya bernilai 0\%-75\%. Vandeputte et al. (2004) melaporkan bahwa pada yuwana ikan mas strain Hungarian synthetic mirror carp berumur delapan minggu yang dipelihara secara komunal mempunyai nilai heritabilitas karakter pertumbuhan (bobot) sebesar 33\%. Pada strain yang sama, Vandeputte et al. (2008) juga menganalisis nilai heritabilitas ikan mas tersebut pada ukuran yang lebih besar, dan mendapatkan nilai heritabilitas karakter bobot sebesar 31\%-44\%. Wang et al. (2006) memperoleh nilai heritabilitas sebesar $25 \%$ untuk karakter bobot badan ikan mas di China berumur delapan bulan dan 30\% pada umur 20 bulan. Ninh et al. (2011) melaporkan bahwa nilai heritabilitas karakter bobot ikan mas di Taiwan sebesar 25\%-32\%. Penelitian pada jenis ikan carp lainnya, yaitu silver carp menunjukkan bahwa nilai heritabilitas karakter biomassa panen sebesar 42\%-93\% (Gheyas et al., 2009). Berdasarkan hasil beberapa penelitian tersebut terlihat bahwa analisis nilai heritabilitas suatu populasi ikan mempunyai variasi yang sangat tinggi. Hal ini karena analisis heritabilitas dipengaruhi oleh jenis dan umur ikan, desain dan metode penelitian serta kondisi lingkungan di mana penelitian tersebut dilakukan. Nilai heritabilitas suatu populasi ikan menjadi sangat spesifik bagi populasi ikan tersebut dan berlaku pada waktu, lokasi serta kondisi lingkungan tertentu.

\section{KESIMPULAN DAN SARAN}

\section{Kesimpulan}

Nilai diferensial seleksi yang tinggi $(286,27$ g dan 280,39 g) didukung dengan estimasi heritabilitas yang baik (42\% dan 30\%) pada kedua populasi ikan mas strain Rajadanu pada penelitian ini memberikan harapan yang baik terhadap peningkatan laju pertumbuhan generasi berikutnya sebesar $45,27 \%$ dan $33,96 \%$.

\section{Saran}

Hasil analisis respon seleksi dan peningkatan mutu genetik (genetic gain) populasi ikan mas ini perlu dievaluasi melalui pengamatan karakter pertumbuhan generasi berikutnya. Hasil pengamatan juga dapat digunakan untuk menganalisis nilai heritabilitas dalam arti sempit atau heritabilitas nyata (realized heritability) populasi ikan mas sehingga dapat diketahui penyimpangan (bias) yang mungkin terjadi akibat penggunaan heritabilitas dalam arti luas (broad sense of heritability) pada penelitian ini.

\section{UCAPAN TERIMA KASIH}

Penelitian ini dibiayai oleh Anggaran Pendapatan dan Belanja Negara (APBN) melalui DIPA No. 0187/032-1 1.2.01/12/2011 di Balai Penelitian Pemuliaan Ikan, Sukamandi. Terima kasih disampaikan kepada semua teknisi yang telah membantu penyelesaian kegiatan ini. Selain itu, terima kasih juga disampaikan kepada para pakar di Jejaring Pemuliaan Ikan Mas Nasional, para evaluator dalam seminar hasil penelitian 2011 dan kepada dewan redaksi atas segala saran, masukan dan perbaikan terhadap makalah ini.

\section{DAFTAR ACUAN}

Anonim. 1999. Statistik Perikanan Indonesia 1997. Direktorat Jenderal Perikanan Budidaya. Jakarta.

Ariyanto, D., Hayuningtyas, E.P., \& Syahputra, K. 2010a. Evaluasi daya tahan lima strain ikan mas (Cyprinus carpio) terhadap KHV. Seminar hasil penelitian LRPTBPAT tahun 2010. Sukamandi, 13-14 Desember 2010, $9 \mathrm{hlm}$.

Ariyanto, D., Hayuningtyas, E.P., \& Syahputra, K. 2010 b. Pembentukan populasi dasar ikan mas (Cyprinus carpio) tahan KHV. Seminar hasil penelitian LRPTBPAT tahun 2010. Sukamandi, 13-14 Desember 2010, $8 \mathrm{hlm}$. 
Boyd, C.E. 1990. Water Quality in Pond for Aquaculture. Alabama: Auburn University Press, $482 \mathrm{pp}$.

Falconer, D.S. 1981 . Introduction to quantitative genetics. $2^{\text {th }}$ Ed. Longman, New York, $340 \mathrm{pp}$.

Fjalestad, K.T., Gjedrem, T., \& Gjerde, B. 1993. Genetic improvement of disease resistance in fish: an overview. Aquaculture, 111:6574.

Flajshans, M. \& Hulata, G. 201 1. Common carpCyprinus carpio. http://genimpact.imr.no/ _data/page/7650/common_carp.pdf. [diakses tanggal 19 April 2011 ].

Gheyas, A.A., Woolliams, J.A., Taggart, J.B., Sattar, M.A., Das, T.K., McAndrew, B.J., \& Penman, D.J. 2009. Heritability estimation of silver carp (Hypophthalmichthys molitrix) harvest traits using microsatellite based parentage assignment. Aquaculture, 294: 187193.

Hardjosubroto, W. 1994. Aplikasi pemuliabiakan ternak di lapangan. PT. Grasindo Indonesia, Jakarta, $284 \mathrm{hlm}$.

Hulata, G. 1995. A review of genetic improvement of the common carp (Cyprinus carpio L.) and other cyprinids by crossbreeding, hybridization and selection. Aquaculture, 129: 143-155.

Kirpichnikov, V.S., Ilyasov, J.I., Shart, L.A., Vikhman, A.A., Ganchenko, M.V., Ostashevky, A.L., Simonov, V.M., Tikhonov, G.F., \& Tjurin, V.V. 1993. Selection of Krasnodar common carp (Cyprinus carpio L) for resistance to dropsy: principal, results and prospects. Aquaculture, 111:720.

Nielsen, H.M., Ødegård, J., Olesen, I., Gjerde, B., Ardo, L., Jeney, G., \& Jeney, Z. 2010. Genetic analysis of common carp (Cyprinus carpio) strains I: Genetic parameters and heterosis for growth traits and survival. Aquaculture, 304: 14-21.

Ninh, Ng.H., Ponzoni, R.W., Nguyen, Ng.H., Woolliams, J.A., Taggart, J.B., McAndrew, B.J., \& Penman, D.J. 2011 . A comparison of communal and separate rearing of families in selective breeding of common carp (Cyprinus carpio): Estimation of genetic parameters. Aquaculture, 322-323: 39-46.

Noor, R.R. 2000. Genetika Ternak. Penebar Swadaya, Jakarta, $200 \mathrm{hlm}$.

Rukmono, D. 2005. Kebijakan pengelolaan kesehatan ikan Direktorat Kesehatan Ikan dan Lingkungan. Di dalam Supriyadi, H. \& Priono, B. (Eds). Strategi pengelolaan dan pengendalian penyakit KHV. Pusat Riset Perikanan Budidaya, Jakarta, hlm. 1-6.

Sunarto, A. 2005. Epidemiologi penyakit Koi Herpes Virus (KHV) di Indonesia. Strategi pengelolaan dan pengendalian penyakit KHV. Pusat Riset Perikanan Budidaya, hlm. 31-39.

Sunarto, A., Rukyani, A., \& Itami, T. 2005. Indonesian experience on the outbreak of Koi Herpes Virus in Koi and Carp (Cyprinus carpio). Bull. Fish. Res. Agen. Supplement, 2: 15-21.

Taukhid, Sunarto, A., Koesharyani, I., Supriyadi, H., \& Gardenia, L. 2005. Strategi pengendalian penyakit Koi Herpes Virus (KHV) pada ikan mas dan koi. Di dalam Supriyadi, H. \& Priono, B. (Eds). Strategi Pengelolaan dan Pengendalian Penyakit KHV. Pusat Riset Perikanan Budidaya, Jakarta, hlm. 4160.

Tave, D. 1993. Genetic for fish hatchery managers. $2^{\text {nd }}$ ed. AVI. Publishing Company. Inc. Connecticut, $122 \mathrm{pp}$.

Vandeputte, M. 2003. Selective breeding of quantitative traits in the common carp (Cyprinus carpio): a review. Aquat. Living Resour., 16: 399-407.

Vandeputte, M., Kocour, M., Mauger, S., DupontNivet, M., De Guerry, D., Rodina, M., Gela, D., Vallod, D., Chevassus, B., \& Linhart, O. 2004. Heritability estimates for growthrelated traits using microsatellite parentage assignment in juvenile common carp (Cyprinus carpio L.). Aquaculture, 235: 223236.

Vandeputte, M., Kocour, M., Mauger, S., Rodina, M., Launay, A., Gela, D., Dupont-Nivet, M., Hulak, M., \& Linhart, O. 2008. Genetic variation for growth at one and two summers of age in the common carp (Cyprinus carpio L.): Heritability estimates and response to selection. Aquaculture, 277: 713.

Wang, C., Li, S., Xiang, S., Wang, J., Liu, Z., Pang, Z., Duan, J., \& Xu, Z. 2006. Genetic parameter estimates for growth-related traits in Oujiang color common carp (Cyprinus carpio var. color). Aquaculture, 259: 103107.

Warwick, J.W., Astuti, M., \& Hardjasubroto, W. 1995. Pemuliabiakan Ternak. Gajahmada University Pres. Yogyakarta, $485 \mathrm{hlm}$. 